\title{
ENVIRONMENTAL SUSTAINABILITY: WORLDVIEW, PHILOSOPHY AND TEACHINGS
}

\author{
Salman Ahmed Shaikh* \\ Abdul Ghafar Ismail** \\ Muhammad Hakimi Mohd Shafiai***
}

\begin{abstract}
Economic choices influenced by animalistic instincts in an ethically neutral framework have not only resulted in huge disparities in distribution of income, wealth and standards of living, but, as we now realise, they have also resulted in an unprecedented loss to ecology and environment with catastrophic consequences for future generations. More than ever, economics as a discipline of knowledge needs an ethical base in order to rekindle a spiritual rationality that can enable us to take into account equity considerations more explicitly in economic choices, both at the individual and at the societal level. This paper explains how Islamic economics can help in bridging the gap. The paper explains the teachings of Islam on different environmental issues and shows how the Islamic worldview can help to encourage and reinforce environmentally friendly behaviour and choices.
\end{abstract}

Keywords: Environmental Economics, Resource Economics, Climate Change, Sustainable Development, Islamic Economics

\section{Introduction}

In the early literature on development, per capita GDP was considered a sufficient barometer for judging the level of development in a country. During that period, macroeconomic literature focused on capital accumulation as the primary instrument for ensuring development. In this regard, Haq (1963) developed the concept of functional inequality. However, functional inequality of income and social utility of greed could not ensure the trickle down of economic growth benefits.

Haq (1995) later accepted that humans are the 'means' as well as the 'ends' of any development process or initiative. He finally accepted that 'ends' cannot be sacrificed for the future, even when benefits are certain. Doing otherwise undermines the entire development process; rather than expecting growth to take care of poverty, we should instead take care of poverty. Only then will economic growth become inevitable. 
But, during the last 30 years, a lot of other challenges have sprung up which require a renewed focus on environmental resource conservation, equitable income distribution, intergenerational equity and enhancing social infrastructure. During the $20^{\text {th }}$ century, world population increased by a factor of 4 , industrial output grew by a factor of 40 , energy consumption increased by a factor of 16 , fish harvesting increased by a multiple of 35 and $\mathrm{CO}_{2}$ and $\mathrm{SO}_{2}$ emissions grew 10 times. During 1981-2005, global GDP more than doubled, but much of world's ecosystems were exploited unsustainably.

Is rapid growth accompanied by an equally rapid depletion of environmental resources, a high fiscal deficit and public debt a truly admirable growth model? In the context of this question, the concept of sustainable development has come to the fore. It has been realised that sustainable growth provides widespread benefits and must not come at the expense of fair income distribution or environment quality.

In a World Bank report (2006), it was highlighted that the use of energy per capita in high income countries is more than 5 times that of developing countries. Moreover, and despite having only $15 \%$ of the world's population, high income countries use more than half of the world's energy (World development Indicators, 2006). In the Stern Review (2006), it was highlighted that the United States is the most polluting country in the world and, together with Europe, accounts for around $70 \%$ of the world's pollution.

Mortazvi (2004) pinpoints the root of the problem: he states that the concern over the tragedy of the commons emanates from the fact that Western economics has become a discipline devoid of values. Exploitation of the natural environment can be abated only when individuals consider intergenerational welfare and justice to be important factors in their economic decisions.

Hassan (2006) shares the same line of thought and states that, in the international arena, nothing can help except realisation of common danger, discipline and sacrifice for the common good. Free-riding can hardly be condoned; instead of preservation and restraint, we are borrowing from the future to consume now via the credit-card culture. In other words, we are jeopardising the future of our children, potentially leaving them in a far worse position than ourselves. ASTRÖM (2011) explains that a problematic feature of today's generation is that it considers itself to have the right to limitless ownership without taking into account the responsibilities it has towards society and humanity.

Costanza et al. (1998) estimate that the minimum annual average value of ecosystem services is 1.8 times the global GNP. Hence, the replacement cost is more than the economic output we produce annually. On the other hand, many ecosystem services are literally irreplaceable. 
While the concepts of human capital development and sustainable development are richer than an exclusive focus on economic growth, the focus in the twentyfirst century should aim to look beyond a human-centric perspective to embrace an ecological balance, both now and in the future. Rather than focusing our attention on achieving weak sustainability based on Hartwick's (1977) rule, whereby the net dynamic change in the value of different forms of capital, like physical $(\dot{K})$, human $(\dot{H})$, social $(\dot{S})$ and natural $(\dot{N})$, must be positive overtime (i.e. $\dot{K}+\dot{H}+\dot{S}$ $+\dot{N} \geq 0$ ), we need strong sustainability whereby the value of each of the different forms of capital grows dynamically (i.e. $\dot{K} \geq 0, \dot{H} \geq 0, \dot{S} \geq 0, \dot{N} \geq 0$ ).

In this paper, we present a mathematical interpretation of the Islamic worldview and its implications for behaviour and choices. We also cite specific Qur'anic verses and ahadith to highlight the significance Islam places on ideal socio-ethical and responsible behaviour, especially in the context of humanity as the trustee and custodian of the environment.

\section{Inadequacy of the Neo-Classical Theoretical Framework}

After the Enlightenment, Western social sciences developed under the influence of a Darwinist worldview. This inevitably led to the emergence of extractive institutions at the macro level, which in turn resulted in growing income inequalities and a rapid surge in consumerism. This has now challenged the boundaries of sustainable existence, let alone sustainable development. This secular paradigm has resulted in ethical neutrality, a wedge between the market and social costs of environmental goods and resources. It has also seen an overexploitation of common property resources, free-riding on public goods, and intergenerational inequity in resource distribution.

Mainstream neo-classical consumer theory over-emphasises the role of consumer sovereignty, resulting in an exogenous treatment of preferences in theoretical economic models. Commitment to this paradigm is reflected in various negative social consequences. For instance, some sport stars and showbiz professionals earn sums equivalent to the entire GDP of a poor country. But, neo-classical economics is neutral towards these ends; as long as people can continue to put up dollar votes for their preferences, resources will be allocated for producing, marketing and distributing inessential goods, even if a quarter of the world population lives in poverty. This over-reliance on Pareto efficiency paralyzes the equity and ethical concerns of development policy; under Pareto efficiency, it is inefficient to help millions escape poverty while making any single rich person worse off.

Since mainstream consumer behaviour theory, and as explained by Thaler (1980), is based on a rational maximising model, it describes how consumers 
should choose given the model and its assumptions, but without necessarily describing how they do choose. Although mainstream consumer behaviour theory is normatively based and only claims to be descriptive, in many cases it fails to predict economic choices either because of rigid axioms or simplistic preference structures. Sen (1977) explains the structure's shortcomings as follows:

A person is given one preference ordering, and as and when the need arises this is supposed to reflect his interests, represent his welfare, summarize his idea of what should be done, and describe his actual choices and behavior. Can one preference ordering do all these things? A person thus described may be "rational" in the limited sense of revealing no inconsistencies in his choice behavior, but if he has no use for these distinctions between quite different concepts, he must be a bit of a fool.

Gowdy and Mayumi (2001) correctly argue that the monotonicity axiom is irrelevant in environment goods, where balance and coherence matters more than abundance. The same is true when consumption is analysed with respect to health effects. Just as consumer choice implicitly maintains (or should maintain) a balance with regards to the health effects of consumption, mainstream consumer theory would be much better off if it gave due weight to the balance between ecology, biodiversity and intergenerational equity. This may require incorporating the attribute of 'commitment' in consumer theory (Sen, 1977).

Furthermore, 'Ultimatum Game' reflects the fact that people tend to look at their choice outcomes relatively. The 'Prisoner's Dilemma' highlights the fact that players who choose in a self-centric way are not necessarily doing what is best for them, either individually or collectively. Moreover, Simon (1957) argues that the information processing capability of consumers is more limited in real-world scenarios than in the idealistic assumptions made by rational economic frameworks. Furthermore, recent evidence from behavioural finance and consumer psychology studies point to the fact that consumer information processing capabilities are limited and prone to error. The Alias paradox (1953) and Ellsberg paradox (1961) are good examples of this phenomenon.

In the neo-classical utility maximisation stream of literature, social interactions have been explored by Becker (1974). Becker (1974 \& 1976) explores intrafamily relations, charitable behaviour, merit goods and multi-person interactions giving rise to envy and hatred. But, Becker's analysis is focused on rationalising non-economic behaviour as an economic decision-making process. Later on, Andreoni (1989 \& 1990) explains that people engage in impure altruism when they contribute to charity or donate for public goods. Hence, these charitable acts 
also emanate from self-interest, i.e. to get fame, satisfy ego or change the living environment to improve one's own social experience and relations.

However, it is also clear that these are not the motivations at work when people pay anonymously or when they have non-satiation. Humans are much more than utility-maximising machines; they are as altruistic as they are reckless. Their behaviour and choices reflect social learning and emanate from their worldview. Recent happiness studies also reflect that the countries which score better on happiness indexes are the ones with higher suicide rates. In short, humans are capable of using both material rationality and moral rationality to differentiate right from wrong; they can be influenced to adopt virtue by an inner urge as much as by material interest. In the next section, we discuss how the Islamic paradigm explains human welfare, and in contrast to the vision of the self-centric, utilitymaximising homo economicus.

\section{Human Welfare in the Islamic Paradigm}

There is growing interest in literature on agents with multiple preferences. Kalai et al. (2002), for example, consider a basic model of multiple selves in which choice is optimal according to any one of those selves. Likewise, Green and Hojman (2007) develop a multiple-self model that allows partial inferences of preferences. Recently, Ambrus and Rozen (2008) also develop a multiple-self model.

Here, we do not wish to present a model for empirical analysis. Rather, we desire to present a concise vision of how a person ought to make decisions according to the Islamic worldview, as a worldview composed of information set through Divine guidance, with its own set of incentives and constraints.

We do not need to define multiple selves: according to the Islamic worldview, human welfare encompasses not only economic welfare, but also much more. Sadeq (1987) explains that Islam emphasises a type of welfare which is more comprehensive than just the economic, that is sought in both aspects of human life, i.e. in the worldly and the Hereafter. Chapra (1999) also explains that, while economic development is indispensable, it is not sufficient to realise overall human well-being. In recent years, even the Western concept of development has recognised that there are wider dimensions to human development (Mirakhor and Askari, 2010). 
Hence, the human welfare function can be represented by:

Where:

$$
\mathrm{W}_{\mathrm{h}}=\mathrm{f}\left(\alpha \mathrm{W}_{\mathrm{t}}, \alpha^{\mathrm{m}} \mathrm{W}_{\mathrm{e}}\right)
$$

$\mathrm{W}_{\mathrm{h}}$ is total human welfare in both aspects of human life.

$\mathrm{W}_{\mathrm{t}}$ is human welfare in this worldly life.

$\mathrm{W}_{\mathrm{e}}$ is human welfare in the Hereafter.

We can further explain this model by defining $\mathrm{W}_{\mathrm{t}}$ and $\mathrm{W}_{\mathrm{e}}$. The first of these functions, for example is defined as follows:

$$
\mathrm{W}_{\mathrm{t}}=\mathrm{f}\left(\mathrm{Z}_{\mathrm{t}}\right)
$$

Where $Z_{t}$ is a vector of variables which belong to the category of 'individual specific positive utility gaining factors'.

The constrained set, which is a union of three sets, is defined as follows:

Where:

$$
\mathrm{C}_{\mathrm{S}}=\left\{\mathrm{C}_{\text {worhip }}\right\} \mathrm{U}\left\{\mathrm{C}_{\text {self }}\right\} \mathrm{U}\left\{\mathrm{C}_{\text {society }}\right\} \mathrm{U}\left\{\mathrm{C}_{\text {people }}\right\}
$$

$\mathrm{C}_{\text {self }}=\{$ five times prayers, one month fasting, obligatory charity, hajj pilgrimage (once)

$\mathrm{C}_{\text {self }}=\{$ acts which harm a person's own ethical and spiritual existence

$\mathrm{C}_{\text {society }}=\{$ acts which harm society and its institutions

$\mathrm{C}_{\text {people }}=\{$ acts which harm other people, their rights, freedom or property

Hence, Islam does not deny an individual's right to fulfill their specific material and/or aesthetic desires. It also does not deny temporary indebtedness to achieve these things, as this can help smooth inter-temporal consumption in this world. Where Islam intervenes, however, is in identifying, for our own benefit, the acts which may potentially harm us and/or society - and hence reduce overall human and societal welfare. Although we feel temporary satisfaction in performing some of these potential acts, their long-term impact on our spiritual and ethical existence reduces their contribution to overall human and societal welfare.

Turning to the eternal life welfare function, we can define this as follows:

$$
\mathrm{W}_{\mathrm{e}}=\mathrm{f}\left(\mathrm{Z}_{\mathrm{e}}\right)
$$

Where $Z_{\mathrm{e}}$ is a vector of variables which belong to the category of 'following Allah's commands which will bring non-decreasing positive utility gain in the Hereafter'. These commands do not segregate a human's life into two compartments. Rather, they help humans live this worldly life in obedience to 
Allah and while being responsive and sensitive to the duties they have to carry out with respect to their different roles in life.

Eternal life has no constraint set. Hence, and unlike the usual constraints applied in economics, which limit the optimum value of a function, in the long-run our worldly life constraint set is welfare-maximising. The worship set also reinforces humanity's commitment to not violate the other three sets of constraints. These, which belong to the category of Huquq-ul-Ibaad, are necessary conditions for the welfare maximisation of the self. When they are not violated by individuals, society also benefits. Islam emphasises that humans should embrace spiritual rationality as a complement to material rationality, thereby achieving total human welfare.

The achievement of lasting happiness and non-decreasing positive utility will only happen when both functions, but especially the eternal life function, are maximised. We need both $\mathrm{W}_{\mathrm{t}}>0$ and $\mathrm{W}_{\mathrm{e}}>0$.

Plus, Islam requires people to live modest but decent lives while fulfilling both their own and their family's needs. Islam does not permit monasticism and does not encourage celibacy. Hence, $\mathrm{W}_{\mathrm{t}}$ must not only be positive, but also achieve the threshold of ' $\mathrm{w}_{\mathrm{o}}$ ' where the ' $\mathrm{w}_{\mathrm{o}}$ ' is the minimum standard of living that qualifies as balanced within the bounds of Islam's injunctions, without lavishness and without violating the constraint sets.

The constraints of life may sometimes require a tradeoff between the two functions. In such instances, the priority must be to choose the correct path, as ordained by Allah, for achieving maximum human welfare in the eternal life. It is achieved because of the parameter ' $\alpha$ '. Things that we enjoy in this world will be replaced by similar things in the afterlife, but there they will provide much more utility and will be infinite. The difference between the utility of what is traded off in this life for the afterlife will be given by the positive multiplier in the exponent of parameter ' $\alpha$ ' as part of the eternal life function.

In the previous section, we discussed the self-centric, utility-maximising homo economicus who believes in this worldly life only and aspires to have absolute freedom. In this section, we discussed how the Islamic paradigm explains human welfare. In the next section, we will present a comparison of these two worldviews.

\section{The Contrasting Implications of the Islamic Worldview}

In mainstream economics, utility (satisfaction) is attained when a person consumes the material goods and/or services they have purchased. Even though utility maximisation models allow room for empathy and altruism, they tend to remain neutral towards such matters. 
With a belief in Allah, however, the scope of a Muslim's life and their objectives cannot be so narrow. A Muslim's principal goal is twofold: to seek Allah's pleasure and to succeed in the Hereafter. A Muslim is supposed to make every decision in such a way that it finds Allah's, and not his own, pleasure "as an end in itself."

As per Islam, this world is a place of testing, requiring some people to be privileged and others to be deprived. All are nevertheless tested for patience and thankfulness to Allah, in addition to how they take care of society and its needs. This worldview draws humanity's attention to the fact that the material resources they enjoy are all blessings from Allah and instruments for this 'testing'.

Nevertheless, the tendency to seek worldly pleasure from certain goods and services is natural and not something humanity can completely deny. Rather, the test lies in being able to nurture one's conscience and fight those tendencies so that they do not grow beyond a certain level. Neither the Prophet Muhammad (pbuh) nor the pious caliphs (rta) used any means other than moral persuasion to inculcate righteous behaviour alongside these natural tendencies.

Rather than complimenting humanity for its animalistic tendencies, for always having one eye on material well-being, Islam inculcates piousness, kindness, cooperation and communal responsibility. In some instances, it guides explicitly towards avoiding extravagance, lavishness and using certain products and services which harm a human's ethical existence and well-being. Islamic economics, for instance, incorporates ethical values and excludes various goods which bring either private or collective loss.

Islamic economics brings a long-term perspective to the pursuit of self-interest by informing humans about the positive and negative consequences of their actions and choices for life in the Hereafter. Resultantly, an Islamic economy will have to rely less on regulation and legal governance to encourage ethical behavior. In the secular worldview, due to the absence of an 'afterlife accountability', people with absolute and inviolable property rights can command natural and environmental resources whose potential lifespan is much more than the lives of their owners. If these people do not believe in an afterlife, they can extract and exploit these resources quickly, depriving future generations of their use.

Extinction of species, global warming, climate change, depletion of the ozone layer and massive carbon emissions are all the inevitable result of a secular, individualistic paradigm. Such a worldly view of life is therefore incompatible with sustainability and socially-responsible behaviour. Rather, a dogmatic commitment to a self-centric secular worldview inevitably results in the proliferation of pollution and the destruction of the environment.

Na'iya (2007) suggests that an effective solution to the world's environmental problems lie in a worldview which spells out the relationship between man, nature 
and his Creator, as well as the implications of one's actions in the Hereafter. Religion provides this type of meaningful conditioning, enabling a balance between human aspirations and the world's physical limitations. Religion also promises to overcome the 'limitedness' of this world in heaven. This provides a permanent incentive to choose righteous behaviour as an end in the hope and fear of deterministic results in the Hereafter.

\section{Islam and Environmental Sustainability}

With the concept of 'afterlife accountability', Islam is able to influence intertemporal choice and behaviour. It helps private economic agents (consumers and producers) modify their actions in such a way that they take both externalities and their own welfare into consideration. Afterlife accountability is capable of stimulating positive changes in behaviour in a much more comprehensive and permanent manner than any regulation or material incentive could possibly do.

Imam Ghazali's discussion of 'the protection of progeny' as part of the Maqasid-e-Shari'ah (higher objectives of the Shari'ah) demonstrates Islam's ethical commitment to sustainable existence well before the West developed its reactionary focus on this issue. Islam recognises that humans should incorporate a consideration of social cost into their private actions. If we want clean air, fresh water and proper sanitation, we must also want these things for others, both in the present and the future. The Prophet Muhammad (pbuh) said:

A Muslim is the one who avoids harming Muslims with his tongue and hands. (Sahih al-Bukhari, Vol 1, Book 2, Hadith No. 9)

A realisation of the enormous value of nature and the environment is vital for fostering a culture of care and responsibility towards those things. The Quran refers to nature as ayat (signs). The book of nature is also a revealed scripture, each page of which reveals a truth (Ansary, 2010). Affirmative action towards preserving and conserving the environment is therefore needed, to produce a culture for achieving environmental sustainability. Islam provides the necessary impetus and deterministic rewards for this affirmative action. The Prophet Muhammad (pbuh) said:

There is none amongst the Muslims who plants a tree or sows seeds, and then a bird, or a person or an animal eats from it, but is regarded as a charitable gift for him. (Sahih Al-Bukhari, Vol 3, Book 39, Hadith No. 513)

In another Hadith, the Prophet Muhammad (pbuh) said: 
Whoever plants trees, God will give him reward to the extent of their fruit. (Musnad, Vol 5, Hadith No. 415)

Climate change and environmental degradation is a slow and cumulative process. Likewise, any effort to resurrect the environment also needs to be cumulative and consistent - even small things done collectively and consistently can have a widespread effect. The two-world view of life proposed by Islam encourages socially responsible behaviour as one of the prime determinants of salvation in the Hereafter. The Prophet Muhammad (pbuh) said:

If the Resurrection were established upon one of you while he has in his hand a sapling, then let him plant it. (Musnad Ahmad, Hadith No. 12491)

The Quran informs us that other species also praise and thank the Creator for their blessings. It says: "Do you not see that to Allah bow down in worship all things that are in the heavens and on earth - the sun, the moon, the stars; the hills, the trees, the animals; and a great number among mankind?" (Chapter 22, Verse 18). The single source of creation, as encapsulated in the concept of tawhid (Divine unity), encourages humility, congeniality and peaceful co-existence between different all forms of life. The Prophet Muhammad (pbuh) said:

A good deed done to a beast is as good as doing good to a human being; while an act of cruelty to a beast is as bad as an act of cruelty to human beings.

Also:

Kindness to animals has its promised reward in the Hereafter. (Mishkat al-Masabih, Book 6, Chapter 7, 8:178)

In another narrative, the Prophet (pbuh) was asked whether acts of charity to animals were rewarded by Allah. He replied:

Yes, there is a reward for acts of charity to every living beast. (Sahih Muslim, Book 26, Hadith No. 5577)

M. N. Islam and M. S. Islam (2015) explicate that killing animals for fun or mere sport is strictly prohibited in Islam. In order to protect land, forests and wildlife, the Prophet Muhammad (pbuh) created inviolable zones known as hima and haram in which resources were to be left untouched. Hima applies particularly to wildlife and forestry and usually designates an area where grazing and woodcutting are restricted, or where certain animal species are protected.

According to the Food and Agriculture Organisation, almost half of all the world's food is currently being wasted while one out of every nine people suffer 
from hunger. Islamic principles discourage this type of conspicuous consumption. The Quran says:

But waste not by excess: for Allah loveth not the wasters. (Chapter 6, Verse 141)

When the Prophet Muhammad (pbuh) saw Sa'd performing wudu', he (peace be upon him) said:

"What is this? You are wasting water." Sa'd replied: "Can there be wastefulness while performing ablution?" The Prophet Muhammad (pbuh) replied: "Yes even if you perform it in a flowing river." (Ibn-eMaja, VI, Hadith No. 425)

With our finite resources, we must do more to reduce hunger, malnourishment, and child mortality from easily curable diseases. This requires the transformation of the modern self-centric, self-interested view of life into the social-centric one proposed by Islam. The Prophet Muhammad (pbuh) said:

Among the three types of people with whom God, on the Day of Resurrection, will exchange neither words nor look at is the one who possesses an excess of water but withholds it from others. God will say to him: "Today, I shall withhold from you my grace as you withheld from others the excess of what you had but which you did not create." (Sahih Al-Bukhari, Vol 3, Book 40, Hadith No. 557)

Thus, we see that Islamic environmental ethics can play a catalyst role in increasing commitment, affirmative action and responsible co-existence with the environment.

\section{Conclusion}

In development economics, humans are both the means and the ends of economic growth. However, this growth experience has led to unprecedented levels of poverty and inequality. Historically, there has never been such a disparity between the living standards of various parts of the world as we see now. When ethical neutrality makes us oblivious to the plights of others, it is no surprise if we also become apathetic in our relationship with the environment, causing important implications for the welfare of future generations. This paper has attempted to explain how Islamic economics, with its distinctive ethical principles, can help rectify this problem and reinforce environmentally friendly behaviour and choices.

Lastly, we mention a verse from the Quran which warns us that on the Day of Judgment the seemingly free natural resources we now use and exploit will be 
made to speak of the treatment they received from us on the day when nothing else can be more disadvantageous than to have sinned:

When the Earth is shaken with a violent shaking, and the Earth throws out her burdens, and man says: "What has befallen her?" - on that Day, she shall tell her story! (Chapter 99, Verse 1-4)

\section{Notes}

* Salman Ahmed Shaikh is a PhD scholar in Economics at Universiti Kebangsaan Malaysia. He can be contacted at: salman@siswa.ukm.edu.my

** Prof. Dr. Abdul Ghafar Ismail is head of research division, Islamic Research and Training Institute, Islamic Development Bank and Professor of Islamic Banking and Financial Economics. He is currently on leave from School of Economics, Universiti Kebangsaan Malaysia. He can be contacted at: agibab@ukm.edu.my

*** Dr. Muhammad Hakimi Mohd Shafiai is a Senior Lecturer at Universiti Kebangsaan Malaysia. He can be contacted at: hakimi@ukm.edu.my.

\section{Bibliography}

Allais, M. (1953). "Le comportement de l'homme rationnel devant le risque: critique des postulatsetaxiomes de l'école Américaine", Econometrica, 21 (4), pp. 503 - 546.

Ambrus, A., \& Rozen, K. (2008) “Revealed Conflicting Preferences", Working paper, Harvard University.

Andreoni, J. (1990). "Impure Altruism and Donations to Public Goods: A Theory of Warm-Glow Giving", Economic Journal, 100 (401), pp. 464 - 477.

Andreoni, J. (1989). "Giving with Impure Altruism: Applications to Charity and Ricardian Equivalence", Journal of Political Economy, 97 (6), pp. 1447 - 1458.

Aström, Z. H. (2011). "Paradigm Shift for Sustainable Development: The Contribution of Islamic Economics", Journal of Economic and Social Studies, 1 (1), pp. 73 - 82.

Becker, G. (1974) “A Theory of Social Interactions”, Journal of Political Economy, 82, pp. 1063 - 1093.

Becker, G. S. (1976). "The Economic Approach to Human Behavior", University of Chicago Press: Chicago.

Chapra, M. U. (1999). "Islam and Economic Development: A Discussion within the Framework of Ibn Khaldun's Philosophy of History", Proceedings of the Second Harvard University Forum on Islamic Finance: Islamic Finance into the $21^{\text {st }}$ Century Cambridge, Massachusetts, Center for Middle Eastern Studies, Harvard University, pp. $23-30$. 
Costanza, R., d'Arge, R., De Groot, R., Faber, S., Grasso, M., Hannon, B., \& Raskin, R. G. (1998). "The Value of the World's Ecosystem Services and Natural Capital", Nature, 387, pp. $253-260$.

Ellsberg, D. (1961), "Risk, Ambiguity, and the Savage Axioms", Quarterly Journal of Economics, 75 (4), pp. 643 - 669.

Gowdy, J. M. \& Mayumi, K. (2001). "Reformulating the Foundations of Consumer Choice Theory and Environmental Valuation”, Ecological Economics, 39, pp. 223 237.

Green, J., \& Hojman, D. (2007) "Choice, Rationality and Welfare Measurement", HIE, RR.

Haq, M. (1963). "The Strategy of Economic Planning: A Case Study of Pakistan", Oxford University Press: Karachi.

Haq, M. (1995). "Reflections on Human Development", Oxford University Press: New York.

Hartwick, J. M. (1977). "Intergenerational Equity and the Investment of Rents from Exhaustible Resources”, 67, pp. $972-74$.

Hassan, Z. (2006). "Sustainable Development from an Islamic Perspective: Meaning Implications and Policy Concerns". Journal of King Abdul Aziz University: Islamic Economics, 19 (1), pp: 3 - 18.

Kalai, G., Rubinstein, A., \& Spiegler, R. (2002) "Rationalizing Choice Functions by Multiple Rationales", Econometrica, 70 (6), 2481 - 2488.

Khalid, M. F. (2002). "Islam and the Environment: Social \& Economic Dimensions of Global Environmental Change", Encyclopedia of Global Environmental Change, 5 , pp $332-339$.

Mirakhor, A. \& Askari, H. (2010). "Islam and the Path to Human and Economic Development”, New York: Palgrave Macmillan.

Mortazavi, S. (2004). "Islamic Economics: A Solution for Environmental Protection, Trade, Growth and the Environment". Oxford University.

Na'iya, I. I. (2007). "Environmental Issues \& Islamic Economics: Nature \& Solutions", Proceedings of the $2^{\text {nd }}$ Islamic Conference. Islamic Science University, Malaysia.

Sadeq, A. H. M (1987). "Economic Development in Islam", Journal of Islamic Economics, 1 (1), pp. 35 - 45.

Sen, A. K. (1977). "A Critique of the Behavioral Foundations of Economic Theory", Philosophy and Public Affairs, 6 (4), pp. 317 - 344.

Simon, H. (1957). “Models of Man”, Wiley: New York.

Stern, N. H. (2006). "Stern Review: The Economics of Climate Change", Vol. 30. London: HM Treasury. 
Thaler, R. (1980). "Toward a Positive Theory of Consumer Choice", Journal of Economic Behavior and Organization, 1, pp. $39-60$.

World Bank (2006). "World Development Indicators", World Bank Group. 